\title{
Water Management in the
}

Yellow River Basin of China 
THIS PAGE INTENTIONALLY LEFT BLANK 


\section{Water Management in the Yellow River Basin of China}

BY CHARLES GREER

University of Texas Press

Austin and London 
Grateful acknowledgment is made to the following for permission to reprint previously published material:

The Water Information Center, Inc., 7 High Street, Huntington, New York 11743, for Table 1-1, which originally appeared in The Water Encyclopedia (1970).

American Geographical Society, Broadway \& 15th Street, New York, New York 10032, for Table 6-1, which originally appeared in Geographical Review 63, no. 1 (January 1973).

\section{Library of Congress Cataloging in Publication Data}

Greer, Charles, 1942-

Water management in the Yellow River Basin of China.

Bibliography: $\mathbf{p}$.

Includes index.

1. Water resources development-China-Hwang-ho Valley.

I. Title.

TC502.H8G73 $333.9^{\prime} 1^{\prime} 009511 \quad 78-15303$

ISBN 0-292-79011-2

Copyright (C) 1979 by the University of Texas Press

All rights reserved

Printed in the United States of America 